\title{
13 \\ Hard Power and Regional Diplomacy: The Dibb Legacy
}

\author{
Raoul Heinrichs and William T. Tow
}

To a much greater extent than their US counterparts, Commonwealth governments such as Australia's have maintained a sharp demarcation between both government agencies and those officials who manage their policies, and the independent strategic analysts in academia or in think tanks who provide independent assessments of government policy performance. There are examples of members of US foreign policy and strategic studies establishments who have excelled in manoeuvring between Washington's inner sanctums of policy formulation and prestigious independent venues providing policy commentary Henry Kissinger, Zbigniew Brzezinski, Madeleine Albright and, more recently, Ashton Carter and Jeffrey Bader all come to mind - but few Australian equivalents. In this context, Paul Dibb is the Australian who has most resembled the American model of a policy practitioner. He has been sufficiently nimble and eclectic to bestride both the hard power world of strategic and defence policy analysis and the delicate and often ambiguous world of diplomatic counsel and has engaged in both pursuits with unquestionable excellence.

Tracing how Dibb has managed to do this, particularly during the late Cold War years and in the post-Cold War era, is the primary theme of this chapter. The narrative that follows reveals at least two fundamental strands that merit such a discourse. One is his ability 
to apply his unparalleled understanding of how great power dynamics work in the Asia-Pacific region to specific policy tasks and objectives. It has been no coincidence that Dibb has been tapped on the shoulder by successive Australian foreign ministers and corresponding defence officials to communicate his country's thinking about regional defence and security politics to key policymakers throughout Asia over more than three decades. In turn, he has gained a wealth of knowledge about how those regional actors perceive Australia's role as both a key US ally and a sovereign player in the Asia-Pacific and international security arenas. This has reinforced his reputation as one of the world's premier strategic and defence policy experts while providing him with the flexibility to broaden his growing profile as an accomplished diplomatic councillor. Second, he has orchestrated the strengths and weaknesses of bilateral and multilateral security politics in ways that have facilitated regional confidence-building and Australia's role in it.

Initially, a brief summary is offered on Dibb's background as it relates to Australia's efforts to come to grips with evolving regional security challenges from the late Cold War. The focus then shifts to cover his subsequent contributions as one of Australia's originators of regional confidence-building politics. Lastly, Dibb's latest diplomatic engagement with a 'Track 1.5' initiative (i.e. the Association of Southeast Asian Nations (ASEAN) regional forum (ARF) Eminent and Expert Persons (EEP) group), which was designed to infuse greater viability into that process, is offered as an example of how he has applied his understanding of hard power and regional diplomacy to a daunting implementation of regional dialogue.

\section{Hard-wired for Regional Security}

Given his professional and intellectual background as arguably Australia's premier strategic studies analyst, Dibb's wide-ranging contribution to regional security cooperation is somewhat surprising. He has a long-standing involvement in the processes, discussions and confidence-building agendas of the region's evolving multilateral security architecture. So too has been his ongoing support of that architecture's transition from dialogue to practical cooperation. Dibb himself is the first to acknowledge the apparent contradiction between 
his strategic studies profile and his record as a diplomatic practitioner. 'I arrived at all this from a career in intelligence and defence planning', he notes.

My focus was mostly on 'hard-power': military capabilities; nuclear developments, particularly in the Soviet Union; and the methodological basis of Australian defence policy. When (in the early 1990s) I was approached to help build an agenda for confidence- and trust-building exercises, it just wasn't my natural scene. ${ }^{1}$

In many ways, his misgivings about multilateral security processes are understandable. Like most of his contemporaries in national security policy during the Cold War, Dibb's world-view necessarily rested on a hard-edged, implicit form of realpolitik. ${ }^{2}$ Conceptually, this was not conducive to an overly optimistic view of regionalism, cooperative security, or even, despite some demonstrable successes during detente, measures for resolving strategic mistrust - which many see as essential in the international system. ${ }^{3}$ Yet these were concepts for which there was a newfound enthusiasm in the post-Cold War world, one suddenly liberated from the constraints of the bipolar geopolitical and ideological confrontations of the past 50 years.

There were other challenges. Dibb had been primarily outcomeoriented in his government service; he now faced a world in which process seemed to matter as much as, if not more than, the goals it was intended to produce. 'Patience, patience, patience', he recalls Australia's then Foreign Minister Gareth Evans counselling him before a Track 1.5 dialogue. ${ }^{4}$ For Dibb, the precision and logic that typified his approach to national security, particularly his Review of Australia's Defence Capabilities in $1986,{ }^{5}$ might now be found to be

1 Paul Dibb, interview with the authors, The Australian National University, Canberra, 12 Aug. 2015.

2 See, for example, Paul Dibb, The Soviet Union: The Incomplete Superpower (London: International Institute for Strategic Studies and Macmillan, 1986); Paul Dibb, World Political and Strategic Trends over the Next 20 Years - Their Relevance to Australia, Working Paper No. 65 (Canberra: Strategic and Defence Studies Centre, The Australian National University, 1983). For a discussion of the characteristics of Australian realist thought, see Michael Wesley, 'The Rich Tradition of Australian Realism', Australian Journal of Politics and History, Vol. 55, No. 3 (2009), pp. 324-34.

3 See, for example, John Mearsheimer, 'The False Promise of International Institutions', International Security, Vol. 19, No. 3 (Winter 1994-95), pp. 5-49.

4 Dibb, interview (2015).

5 Paul Dibb, Review of Australia's Defence Capabilities, report to the Minister for Defence (Canberra: Australian Government Publishing Service, 1986). 
less applicable to the amorphous concept of regional security. Linking strategic guidance to capability, optimising Australia's military for a range of credible contingencies, structuring the Australian Defence Force (ADF) in line with the Defence of Australia (DOA) doctrine, all reflected traditional national security policy in a world shaped by power politics. These approaches constituted Dibb's professional world. In terms of regional security cooperation in the era following the end of the Cold War, however, he now faced an ambiguous and daunting task - one over which he had less direct influence - not just responding to the forces of power politics, but exploring the means by which they could be fundamentally ameliorated.

As it happened, none of these challenges proved insuperable to Dibb, either during or after the Cold War. Indeed, at least in some cases, those factors that might otherwise have inhibited Dibb's contribution to regional security cooperation in fact propelled him in the other direction. A number of personal attributes made him suited to the task. Arguably the most important was credibility, defined by the combination of intellectual weight and political skill and the ability to formulate ideas and successfully translate them into policy. By the early 1990s, Dibb was as close to a household name in Australia as defence intellectuals can become. The Dibb Review, as it came to be known, had imposed unprecedented analytical rigour on Australian defence policy. His emphasis on Australia's quest for 'defence selfreliance' cut against a strategic culture of dependence on great and powerful friends that was so deeply ingrained in Australia's psyche it had come to be seen as constitutive of the national identity. Undoing this mindset was no easy feat. It meant, among other things, overcoming entrenched bureaucratic interests, not least within the Defence organisation and the Australian Army, whose traditional primacy among the military services had been upended in favour of a strategy that privileged air and maritime capabilities. If the process was transformational, so were the consequences. As Australia's then foreign minister wrote: 'This new confidence in our defence capability liberated Australian foreign policy. Australian foreign ministers are freer to think about their responsibilities more systematically, and more intricately, than ever before. ${ }^{6}$ It also compelled Australia to think

6 Gareth Evans \& Bruce Grant, Australia's Foreign Relations in the World of the 1990s (Melbourne University Press, 1991), p. 30. 
more systematically about how it would relate diplomatically and strategically with its regional neighbours. It provided a foundation for a broader national security approach that ironically led to Australia, over time, becoming a pivotal force in defining and shaping regional collective security politics.

Dibb's classical work on the Soviet Union, too, contributed to his credibility as an intellectual heavyweight as the transition from a bipolar world to a more complex multipolar one unfolded. No one foresaw the extraordinary confluence of events that brought about the demise of the Soviet Union and the end of the Cold War - but very few had come as close as Dibb. From the early 1980s, he had identified a set of potentially fatal underlying flaws in the Soviet Union: economic stagnation and decline leading to insurmountable pressure on Russian standard of living, Soviet military expenditures and doubt about the Soviet Union's overall political cohesion. ${ }^{7}$ These, he argued, 'could see the Soviet Union's empire eventually begin to crumble ... In the long haul, the very "Russianness" of the Soviet multinational state is in question' $^{8}$

The clarity and foresight of these observations confirmed Dibb's prescience. Time and again, from intelligence to policy to academia, and from issue to issue, Dibb exuded a level of intellectual ability that bode well for his efforts in the world of regional security cooperation. ${ }^{9}$ As Evans has observed, 'Enlisting one of our foremost minds in confidence-building and the Track 1.5 agenda, we felt, itself signified our seriousness and commitment to the tasks. ${ }^{10}$

Finally, there is another, more innate characteristic that made Dibb a good fit for regional security cooperation. An old joke reveals that you can tell an extroverted defence intelligence analyst when they look at your shoes while talking to you. If there is any grain of truth in this, Dibb is a striking exception. As Hugh White explains: 'Paul is a natural diplomat. He has a disarming sense of charm and wit. When he pulls you aside, he has this way of making you feel like you're one of the

\footnotetext{
7 Dibb, The Soviet Union: The Incomplete Superpower (1988).

8 Paul Dibb, World Political and Strategic Trends (1983), p. 11.

9 Dibb has a long list of academic publications from his time in government. This is uncommon amongst members of the Australian Public Service, still less among members of the Australian intelligence community.

10 Gareth Evans, interview with the authors, Melbourne, 3 Sep. 2015.
} 
only people in the room.' ${ }^{11}$ Beyond this, Dibb is intuitively attuned to the way power and influence shape organisational dynamics. He has, as Australia's former 'defence supremo' Sir Arthur Tange once put it, 'a persuasive personality' without being abrasive. ${ }^{12} \mathrm{He}$ also has a sharp memory and an easy interpersonal style. Taken together, these attributes made him almost preternaturally disposed to cultivating the kinds of personal relationships that are important diplomatic currency in Asia. ${ }^{13}$

\section{Dibb goes to China}

Much of Dibb's work on regional security cooperation occurred after the end of the Cold War, once he had left government to head the Strategic and Defence Studies Centre (SDSC) at The Australian National University (ANU) in 1991. It began, however, more than a decade earlier. Then in his 30s, Dibb was appointed by Tange as Deputy Director of the Joint Intelligence Organisation (JIO, the forerunner to today's Defence Intelligence Organisation) in $1978 .{ }^{14}$ From this point to the early 1990s, Dibb was a central actor in two sets of official government-to-government contacts (or 'Track 1' exchanges) - the first with the People's Republic of China (PRC), the second with Japan. In both cases, these strategic relationships were in their infancy. ${ }^{15}$ As a consequence, Australia's official contact with these two critical countries' military and security establishments was in most cases less substantive than procedural, and largely exploratory in nature. Nevertheless, these early contacts helped build the foundations for security relationships. Although not core business for Dibb at the time, they provided him with an entrée into the work that would become a preoccupation in the years to come.

11 Hugh White, interview with the authors, The Australian National University, Canberra, 13 Aug. 2015.

12 Sir Arthur Tange, Defence Policy-Making: A Close-Up View, 1950-1980: A Personal Memoir, Peter Edwards (ed.), (Canberra: ANU E Press, 2008), p. 82.

13 For a discussion of the importance of personal relationships to diplomacy, see Keith Hamilton \& Richard Langhorne, The Practise of Diplomacy: Its Evolution, Theory and Administration (Abingdon: Routledge, 1995), p. 172.

14 Michelle Grattan, 'Dibb to be Intelligence Chief', Age, 10 Oct. 1986.

15 See James Reilly \& Jindong Yuan (eds), Australia and China at 40 (Sydney: UNSW Press, 2012). See also Desmond Ball, 'Whither the Japan-Australia Security Relationship?', Nautilus Institute for Security and Sustainability, APSNet Policy Forum, 21 Sep. 2006, nautilus.org/ apsnet/0632a-ball-html/. 
The 1970s was a period of considerable change in Australia's strategic landscape. ${ }^{16}$ On the one hand, the public articulation of the 'Guam doctrine' (also known as the 'Nixon doctrine') (1969), the withdrawal of British forces from east of Suez, and defeat for the United States in Vietnam augured new uncertainties. On the other hand, new opportunities for Australian diplomacy were emerging as geopolitical shifts were underway in response to widening schisms in the communist world. For two decades since the communist victory in the Chinese Civil War (1949), Chinese foreign and strategic policy had been geared towards undercutting American power wherever it appeared, in the ultimate hope of removing the United States as a predominant player within the Asian balance of power. The resulting tension produced two wars - during Korea and Vietnam, Australia endured two anxious decades of bitter power rivalry in the region.

All of this was modified by Richard Nixon's visit to China and America's subsequent opening to that Asian country. At the heart of the Sino-American 'rapprochement' was a tacit alliance to preclude Soviet expansionism in Asia. ${ }^{17}$ In practice, this meant that America would formalise its recognition of the Chinese Communist Party, while China would do nothing to aggravate the situation in Vietnam or Korea - and, more broadly, would reduce its contest of American power in Asia. ${ }^{18}$ Eager to avoid hastening or strengthening Sino-US rapprochement, the Soviet Union soon accommodated itself to a new era of détente. As Kissinger has pointed out, 'Once America had opened to China, the Soviet Union's best option became seeking its own relaxation of tensions with the United States'. ${ }^{19}$

For Australia, such ongoing geopolitical developments had a soothing strategic effect, although one which took some time to internalise. More immediately, however, it provided the political context in which Australia's opening to China could proceed on the back of Prime Minister Gough Whitlam's historic October 1973 visit to Beijing. With relations established in 1972 and normalised in 1975, and with the

16 See Hedley Bull, 'The New Balance of Power in Asia and the Pacific', Foreign Affairs, Jul. 1971.

17 See Robert Ross, Chinese Security Policy: Structure, Power and Politics (London: Routledge, 2009), p. 25.

18 See Hugh White, The China Choice: Why America Should Share Power (Melbourne: Black Inc., 2012).

19 See Henry Kissinger, Diplomacy (New York: Simon and Schuster, 1994), p. 30. 
relationship accelerating from that point onward, the strategic scene was at least partly set for Dibb's fascinating, if much less well known, 1978 visit to China.

Dibb crossed into mainland China from Hong Kong on 1 August 1978 - the first official visit of an Australian defence intelligence representative to the PRC. Early in the visit Dibb was shown fall-out shelters under Tiananmen Square. Despite Mao Zedong's notorious outward ambivalence to the threat posed by nuclear weapons, this was a potent reminder of the reality of China's strategic nuclear anxieties. ${ }^{20}$ It was also, Dibb knew, intended as a prompt. For China, the purpose of his visit, beyond just 'feeling Australia out', was to garner any available information he may have and be willing to convey about the Soviet Union's strategic intentions and capabilities. ${ }^{21}$ In particular, Dibb's Chinese interlocutors wanted to know anything he could offer on Soviet missile systems. 'They understood our intelligence-sharing arrangements with the United States', Dibb notes. 'They knew that we knew about them [Soviet missile systems], and they wanted to test whether we might be more forthcoming than the US. On that front, to their chagrin, they were bound to be disappointed.'.22 Chinese disappointment was compounded when a People's Liberation Army (PLA) divisional commander made the age-old mistake of trying to drink Dibb under the table. Hungover, they headed for the port city of Hangzhou, and from there to Shanghai, where he was a guest of the three-star garrison commander.

Shanghai turned out to be the setting for both the low point and high point of Dibb's visit: the former involved a night at the Chinese opera (an assault on Dibb's auditory senses); the latter, an unexpected visit to the PLA Navy's submarine building yard and an up-close view of a Romeo-class submarine - at the time, China's most potent naval platform. This was surprising because the physical characteristics of submarines are among states' most closely guarded military secrets. ${ }^{23}$ Back in Canberra, Defence's naval intelligence wonks were

20 See Jeffrey G. Lewis, The Minimum Means of Reprisal: China's Search for Security in the Nuclear Age (Cambridge: MIT Press, 2007).

21 Dibb, interview (2015).

22 Dibb, interview (2015).

23 The question of whether Dibb was the first Westerner to tour a Chinese submarine base remains a matter of conjecture. According to James Lilley, then US ambassador to China, the honour belongs to him. Dibb disagrees. 
disappointed to discover that, as a strategic rather than a technical analyst, the finer details of the Romeo's properties had eluded him altogether.

In any case, this was not Australia's purpose in dispatching Dibb to China. Rather, it was for him to initiate strategic contacts at the official level, to begin the process of consolidating Australia's broader diplomatic relations with China, and to cultivate some personal linkages that might serve as a foundation for deeper engagement. In this sense, the visit was a success. While Australia's defence relationship with China remained tentative, defence attachés were formally swapped. This allowed for a gradual increase in contact between the two defence organisations, and for the incremental institutionalisation of a defence relationship that has further evolved today.

\section{Dibb and Japan}

Dibb's next major foray into confidence-building and regional security cooperation helped lay the groundwork for the establishment of Australian mechanisms for regular official exchanges and dialogues with Japan on shared strategic challenges. It may seem strange to note the fundamentally underdeveloped nature until the early 1990s of Australia's security relationship with Japan against the backdrop of the dramatic acceleration of strategic relations in recent years. ${ }^{24}$

From the 1970s, however, the most pronounced feature of Australia's security relationship with Japan was, as Aurelia George Mulgan notes, 'a rather dull predictability, a relationship that appeared to have reached the limits of its potential, without much scope for dramatic expansion or diversification' ${ }^{25}$ While trade and investment ties increased through the 1970s and 1980s, politico-strategic relations

24 This has brought about the Joint Declaration on Security Cooperation (2007), a Defence Acquisitions and Cross-Servicing Agreement (2010), as well as the possibility of the acquisition by Australia of a variant of the Japanese Soryu-class submarine. If this latter step is realised, the deal would be Japan's first major postwar defence export agreement. See Malcolm Cook, 'The Quiet Achiever: Australia-Japan Security Relations', Analysis (Sydney: Lowy Institute for International Policy, 2011). See also Chris Brooks, 'Australia-Japan Security Relations: Improving on a Best-Friends Relationship', Indo-Pacific Strategic Papers (Canberra: Australian Defence College, 2014).

25 Aurelia George Mulgan, 'Australia-Japan Relations: New Directions', ASPI Strategic Insights (Canberra: Australian Strategic Policy Institute, Jul. 2007), p. 2. 
continued to be inhibited by a range of factors: the absence of any compelling strategic requirement, the bitter legacy of the Second World War, growing Australian uncertainties about the intentions of an increasingly powerful Japanese economic actor, and Japan's own strict constitutional limitations on its external strategic relations.

Concrete interaction on security issues commenced in the mid-1970s at the instigation of the Australian Secret Intelligence Service (ASIS), but such cooperation was limited. ${ }^{26}$ Although ASIS took the lead, bilateral cooperation expanded in the late 1980s into defence intelligence. As head of the National Assessments Staff (NAS) at Defence, this is where Dibb's exposure to Japan began in earnest. By the time Dibb had departed as Director of the JIO in 1986, incorporated agreements with the intelligence directorates of each of the branches constituting Japan's Self-Defense Force (SDF) were in place. ${ }^{27}$

At the same time, Australia's security cooperation with Japan began to evolve out of intelligence and into the world of policy. That this occurred in lock-step with Dibb's appointment as the Deputy Secretary for Defence in 1988 was no coincidence. The creation of regular mechanisms for dialogue on shared strategic challenges was seen by Canberra as an important confidence-building measure (CBM) and a crucial base on which to build the relationship.

In March 1990 Dibb, together with then Vice Chief of the Defence Force, Vice-Admiral Alan Beaumont, led an Australian delegation to Japan for the first Track 1 security dialogue between the two countries. On the Japanese side, discussions were facilitated by Dibb's friend, Yukio Satoh, then Director-General in the Analysis, Research and Planning Bureau of Japan's Ministry of Foreign Affairs (MOFA). The two had discovered that they shared a birthday, and Satoh began lightheartedly referring to Dibb as his 'blood-brother'. As Dibb explains, 'In Japan, personal connections really matter!'28

In spite of the obvious congeniality between these two key players, overall discussion about Australia-Japan security was still characterised by considerable Japanese sensitivity. 'Remember, this was the first time they had done anything like this with any country

26 Ball, 'Whither the Japan-Australia Security Relationship' (2006).

27 Ball, 'Whither the Japan-Australia Security Relationship' (2006).

28 Dibb, interview (2015). 
other than the US', notes Dibb. Indeed, the Japanese delegation was limited to civilians from the Japan Defense Agency (JDA) and MOFA. Senior officials had proscribed attendance of uniformed personnel from the SDF, unwilling to risk transgressing Japan's normative and legal constraints by approving direct military-to-military talks with forces not from the United States.

While discussions remained exploratory rather than substantive, the agenda was nevertheless wide ranging. Issues included the future of the (by then beleaguered) Soviet Union and its implications, and the scope and limits of each country's respective alliance with the United States. In particular, Dibb's Japanese interlocutors were eager to learn more about Australia's 'full-knowledge-and-concurrence' arrangements at the joint facilities at Pine Gap, Nurrungar and North West Cape. ${ }^{29}$ This came as no surprise to Dibb. Entrapment dilemmas as a result of US sovereignty over bases throughout the Japanese archipelago had for decades been a vexed issue in Japan, and it remained a matter of ongoing concern. For Australia's part, the talks were an opportunity to canvass Japanese views of north-east Asia. A resident power, Japan could be expected to have a more nuanced understanding of China, Taiwan, North Korea and South Korea, and the Russian far east.

The Dibb-Beaumont talks, as they came to be known, continued until 1995, when they were supplanted by annual Track 1 political-military and military-military discussions. Yet the success of the initial round - and of Dibb's leadership - was reflected in swift developments in the Japan-Australia security relationship from that point on. In May 1990, Japanese Defence Minister Yoso Ishikawa became the first to visit Australia. The visit was reciprocated by Australian Defence Minister Robert Ray in 1992, and relations gathered steady momentum throughout the 1990s.

Today, Australia-Japan security relations span the full range of strategic issues and forms of cooperation. ${ }^{30}$ The intelligence relationship has been nurtured to unprecedented intimacy. Official dialogues have spawned annual $2+2$ ministerial (defence and foreign minister) talks, and leadership summits are a regular occurrence, often

29 For a detailed discussion, see Desmond Ball, A Suitable Piece of Real Estate: American Installations in Australia (Sydney: Hale \& Iremonger, 1980).

30 See Australian Department of Foreign Affairs, 'Japan Country Brief', Canberra, 2015, dfat. gov.au/geo/japan/Pages/japan-country-brief.aspx. 
on the sidelines of the region's major multilateral meetings. A trilateral strategic dialogue has been institutionalised between Australia, Japan and the United States, including regular joint military exercises. The Joint Declaration for Security (2007) provides a broad foundation for cooperation on everything from counterterrorism and border security to maritime security, counter-proliferation and disaster relief operations.

In 2013, when Prime Minister Tony Abbott openly declared Japan to be Australia's 'closest friend in Asia', it appeared possible, perhaps likely, that relations might even coalesce into a formal alliance. ${ }^{31}$ This remains a highly contentious issue in Australian strategic policy ${ }^{32}$ as to whether it would be a prudent move for Australia in light of Japan's uncertain strategic future. Whatever the case, it is ultimately not Dibb's problem, or even his legacy. Dibb's task was to get AustraliaJapan security relations off the ground floor. To that end, he executed his mission with trademark skill, energy and finesse.

\section{World in Flux: After the Cold War}

Like the 1970s, the post-Cold War world of the early 1990s presented itself as a dizzying one for the makers of Australian foreign and strategic policy. Once again, elements of continuity and discontinuity interacted to produce a range of conflicting trends in Australia's security environment. ${ }^{33}$ As Dibb pointed out in the inaugural Melbourne Asia Policy Paper, a sense of policy drift had overtaken the traditional rationales for the United States to value Australia. Expectations for a 'new world order' underwritten by globalisation and democracy (and, by implication, to be shaped by multilateral approaches to order-building) were running high in Washington. ${ }^{34}$ The sudden disintegration of the Soviet Union removed the primary sources of global ideological and geopolitical confrontation. For the first time in almost 50 years, the world appeared to have been freed

31 See Mark Kenny, “Tony Abbott says "Japan is Australia's Closest Friend in Asia"', Sydney Morning Herald, 9 Oct. 2013.

32 See Hugh White, 'Abbott Should Think Twice Before Becoming Friendly with Japan', Age, 8 Jul. 2014.

33 See Evans \& Grant, Australia's Foreign Relations (1991).

34 Paul Dibb, Australia's Alliance with America, Melbourne Asia Policy Papers, Vol. 1, No. 1 (University of Melbourne, Mar. 2003), p. 9. 
from the ever-present spectre of apocalyptic nuclear war. Regionally, the lead times on development of military capabilities by other regional powers remained far enough over the horizon not to cause alarm. ${ }^{35}$ Australia's ally, the United States, suddenly found itself alone at the top of the international pecking order.

The United States was facing momentous choices. ${ }^{36}$ Whichever direction it took would have profound implications for Australia. If the United States eventually chose to remain deeply engaged in Asia, if it retained its alliances and deployed its now overwhelmingly preponderant military power in support of them, Australia could probably 'breathe easy'. Canberra could continue to enjoy the region's strategic quiescence, with all the benefits and opportunities that entailed. At the time, however, that outcome felt far from assured. The dissolution of the Soviet Union had robbed the Asia-Pacific of what many reasonably assumed was the only compelling reason for Far East assignment of American power. Again, it was Dibb that best posed the obvious question: 'What does alliance mean when the discipline of a common threat has gone?'37 The 1994 Defence White Paper offered a less than emphatic response: 'The United States will remain a major contributor to security over the next fifteen years, but it will neither seek nor accept primary responsibility for maintaining peace and stability in the region. ${ }^{38}$

The possibility of a significantly diminished US role loomed as a frightening one. In the worst case, US retrenchment from Asia threatened to create a vacuum, bringing into play the full range of strategic risks to Australia that American power had hitherto suppressed: the resumption of Sino-Japanese rivalry, the attainment of dominance by one or the other, or worse still, a war followed by the emergence of a new hegemon. ${ }^{39}$ There were other uncertainties too: the potential realisation of North Korea's nuclear ambitions and its unresolved conflict with the South, territorial disputes in the South

35 See Paul Dibb, The Regional Security Outlook: An Australian Viewpoint, Working Paper No. 262 (Canberra: Strategic and Defence Studies Centre, The Australian National University, 1992), p. 1.

36 See Charles Krauthammer, 'The Unipolar Moment Revisited', The National Interest (Winter 2002/2003).

37 Dibb, The Regional Security Outlook (1992), p. 9.

38 Commonwealth of Australia, Defending Australia: Defence White Paper 1994 (Canberra: Australian Government Publishing Service, 1994), p. 9.

39 See Thomas Christensen, 'China, the US-Japan Alliance, and the Security Dilemma in East Asia', International Security, Vol. 23, No. 4 (1999), pp. 49-80. 
China Sea, an Indo-Pakistani conflagration, Taiwan's indeterminate status, or the possible proliferation of weapons of mass destruction to offset asymmetric conventional military balances. Each of these could have serious implications for Australian security. ${ }^{40}$ Even if worst cases did not eventuate, there was still a sense that Australia needed to better develop a strategic environment shaped by the attitudes and approaches of regional countries themselves. ${ }^{41}$

In terms of regional security cooperation, the uncertainties of this new era created the impetus for two overlapping sets of objectives. The first involved exploring new bilateral avenues for security cooperation with regional states in order to directly augment Australian national security - for example, exchanges in personnel or intelligence, or joint military exercises (this kind of cooperation was Dibb's forte). The second, which was more ambitious and more multilateral, involved taking the lead in processes that, it was hoped, could temper the forces of power politics unleashed by a new strategic order.

While the objectives were distinct, the means of pursuing them were similar. Each would require CBMs to overcome initial suspicion and mistrust and to develop necessary habits of cooperation. Each would have to avoid becoming impeded by excessive formality or held up by diplomatic sensitivities. In that sense, they would benefit from the use of unofficial channels, at least in the early stages. And each would involve a role for Dibb, albeit in slightly varying capacities.

The first objective saw Dibb, now in academia at ANU, reprise his diplomatic role to lead Australian delegations in a series of semiofficial Track 1.5 dialogues throughout the region. These included follow-up discussions throughout the early to mid-1990s with China and Japan, and later establishing new forms of dialogue and security interaction with such regional actors as South Korea and Vietnam. The Track 1.5 format was a kind of 'Goldilocks option'. It was structured so as to avoid falling into the realm of abstraction, which was a risk of a fully unofficial (or Track 2) process, but less rigid than Track 1 engagements. Track 1.5 dialogues were officially sanctioned, and they included a substantial number of Australian officials and their regional counterparts acting in their official rather than private

40 See Dibb, The Regional Security Outlook (1992), pp. 1-4.

41 Australian Department of Defence, Defending Australia (1994), p. 85. 
capacities, in contrast to the more informal Track 2 dialogues. ${ }^{42}$ Dialogue was intended to fulfil a number of intermediate purposes: foster personal relationships, bolster transparency and trust, explore mutual perceptions of the regional security environment and take early steps to carve out some mutual understandings about the potential direction of future strategic cooperation.

For the architects of these dialogues, Dibb's lead role made good sense. He was now an academic, so at liberty to be more open, but still highly attuned to government priorities and requirements. He had personal networks in Australia and overseas and on all sides of politics. As a former intelligence specialist, he was particularly adept at probing his interlocutors on the most salient issues while steering discussions away from more trivial aspects. Behind the scenes, he could process information and assimilate it into a broader strategic framework to convey useful, actionable information to Canberra. According to White:

These talks were not designed to push strong policy agendas. They were exploratory kind of intelligence gathering missions on how changes in Asia's order were being interpreted by countries we didn't have a long track-record of talking to about these things. ${ }^{43}$

\section{Practical Proposals}

Dibb's efforts in relation to the second objective centred around his role in drafting the Australian Paper on Practical Proposals for Security Cooperation in the Asia Pacific Region (1994). He had been designated for this role by his co-author, Foreign Minister Evans. In seeking to further the paper's objectives, Dibb also chaired a major Track 1.5 meeting in Canberra in November 1994. This was an intersessional seminar comprised of officials from the foreign and defence ministries of the 18 members of the ASEAN ARF, as well as a number of leading regional academics. The key outcomes were to be carried forward at the 1995 ARF Senior Officials Meeting in Brunei. The conclusions

42 See Desmond Ball \& Brendan Taylor, 'Regional Security Cooperation', in Desmond Ball \& Robert Ayson (eds), Strategy and Security in the Asia-Pacific (Crows Nest: Allen \& Unwin, 2006), p. 273.

43 White, interview, (2015). 
drawn by this study and the dialogue processes it elicited proved to be a substantial component of the region's subsequent CBM politics. Accordingly, it is assessed in some detail here.

The Australian Paper treatise had its origins in the 1993 ASEAN Post-Ministerial Conference on regional CBMs. It was submitted for discussion at the ARF Senior Officials Meeting (May 1994), and from there went before the first ministerial-level meeting of the ARF, in Bangkok, later the same year. While the formal terms of reference for the ARF were set out in a concept paper, adopted in August 1995, the organisation's general approach to CBMs - an emphasis on sensitivity and trust as an essential precondition to deeper forms of cooperation - reflected many of the key themes and principles outlined in Evans's and Dibb's submission.

The Australian Paper, in turn, built on the scholarly contributions to the field of CBMs that Dibb was making as head of The Australian National University's SDSC. ${ }^{44}$ The document was designed, first, to be 'strategic', embedded firmly in concerns about the evolution of Asia's security environment after the Cold War. Second, it was intended to be diplomatic. The terminology used in the paper was deliberately employed to distinguish it from the traditional language of arms control and international security, which harked back to the previous era of superpower confrontation. According to Evans, 'Cold War language and concepts were not appropriate to the entirely different political, cultural and strategic situation in the Asia Pacific'.$^{45}$ Third, the paper was geared to be realistic. It explicitly precluded the possibility of addressing 'Asia Pacific security cooperation in all its dimensions', instead limiting its focus to 'military cooperation and defence issues' ${ }^{46}$ It adopted a graduated approach, categorising specific trust-building measures not on their urgency, but rather by how easily they might

44 See, for example, Paul Dibb, Focusing the CSBM Agenda in the Asia-Pacific Region: Some Aspects of Defence Confidence Building, Working Paper No. 256 (Canberra: Strategic and Defence Studies Centre, The Australian National University, 1992). Also see Paul Dibb, How to Begin Implementing Specific Trust-Building Measures in the Asia-Pacific Region, Working Paper No. 288 (Canberra: Strategic and Defence Studies Centre, The Australian National University, 1994).

45 Gareth Evans \& Paul Dibb, Australian Paper on Practical Proposals for Security Cooperation in the Asia Pacific Region (Canberra: Strategic and Defence Studies Centre and Australian Department of Foreign Affairs and Trade, 1994), p. 1.

46 Evans \& Dibb, Australian Paper (1994), p. 3. 
be implemented. It deliberately avoided setting out time frames, and it included a specific list of 'areas where information-sharing is unlikely'. ${ }^{47}$

Finally, the paper was intensely practical. '[D]ialogue', noted Evans in his remarks to the 1994 conference, 'must have a specific focus and content. ${ }^{48}$ CBMs were divided into three categories based on the level of trust needed to implement them. Category 1 initiatives were the principal focus and included proposals for a limited exchange of military information, which would build transparency; a regional security studies centre to serve as a centralised repository for government-supplied information; a maritime information database, which would house data on all areas pertinent to shipping; strategic planning exchanges, which would create a regular mechanism in which defence planners could share perceptions on regional security developments; observers at military exercises; and peacekeeping training, which would focus on the 'peculiar requirements' of these kinds of military operations. Categories 2 and 3 involved more complex and structured forms of confidence-building — such as maritime cooperation, a regional arms register, and an incidents at sea agreement. These were contingent on the kind of trust which, it was hoped, would result from the institutionalisation of Category 1 CBMs.

Twenty years on, the legacy of the Australian Paper is mixed. This has less to do with the quality of the paper or the practicality of its proposals than with institutional constraints. In terms of direct influence on the ARF, the paper's impact has been limited to establishing the incremental approach that the organisation would take to building confidence. The intersessional meeting held in Canberra is noted in the ARF chairman's statement issued at the second annual ARF meeting convened at Brunei in August 1995. But any direct proposals flowing from it seem not to have gone much further than that.

Some progress has been made by the ARF in areas that reflect the paper's proposals. A range of enhanced contacts have occurred, including high-level visits, and exchanges between military academies and staff colleges. Defence white papers, especially about north-east Asia, are

47 Evans \& Dibb, Australian Paper (1994), p. 5.

48 Gareth Evans, 'Address to the Seminar on the Building of Confidence and Trust in the Asia Pacific', Canberra, 24 Nov. 1994. 
being promulgated more regularly, in part to serve the purposes of transparency. ${ }^{49}$ Disaster relief exercises have become an important component of the agenda. The organisation has also spawned a number of smaller, more focused dialogues. But overall, the ARF's record on practical cooperation has been impeded by organisational malaise. The overriding emphasis on consensus and non-interference as the guiding principles have imposed structural limits on the ARF's capacity to progress beyond preliminary CBMs, much less tackle the more exacting tasks of preventive diplomacy or conflict resolution. By 2007, Dibb himself was evincing increasing despondence, declaring the ARF little more than a 'talk-shop'. ${ }^{50}$

\section{Eminent and Expert Persons Group}

Despite these frustrations, Dibb did not give up. His next contribution to regional security cooperation involved representing Australia at the ARF EEP group every year from 2006 to 2015. Each member state could nominate up to five experts. Once again, Dibb was an obvious choice for Australia given his credentials in the field. ${ }^{51}$ His nomination by the Department of Foreign Affairs and Trade (DFAT) found ready acceptance from its then Minister, Alexander Downer. He had appointed Dibb a member of his Foreign Policy Advisory Council for the nine years it existed from 1998.

The EEP group was created in 2002 as a Track 1.5 complement to the ARF. It was established as a professional repository of ideas, research and advice for the ARF's Track 1 processes. The meeting is open to all countries that are members of the ARF. Chairmanship rotates annually, with the co-chair designated host of the following year's meeting. The outcome is a chairman's report, including recommendations that are carried into the official ARF ministerial process.

49 See Ball \& Taylor, 'Regional Security Cooperation' (2006), p. 273.

50 Paul Dibb, 'A New Defence Policy for a New Strategic Era?', in Clive Williams \& Brendan Taylor (eds), Countering Terror: New Directions Post 9/11, Canberra Papers on Strategy and Defence No. 147 (Canberra: Strategic and Defence Studies Centre, The Australian National University, 2003), p. 64.

51 The other Australian participants nominated were Hugh White, Ivan Shearer, Sam Bateman and Alan Dupont. 
Three factors underpinned the EEP group's creation. The first was a recognition of the scale of emerging regional strategic uncertainties in the twenty-first century: the rise of China and India, the North Korean nuclear issue, the emergence of terrorism as a central issue after the September 2001 attacks in the United States, and the war in Afghanistan. The second factor was the creeping sense of stagnation at the Track 1 level, especially the inability of the ARF to evolve beyond preliminary CBMs into the realm of preventive diplomacy. The third was concern about the potential emergence of competing new regional institutions.

Although the EEP group was established in 2002, it did not meet for the first time until 2006. Dibb was, to borrow Dean Acheson's landmark phrase to describe his own role at the inaugural EEP group meeting held in South Korea, 'present at the creation'.$^{52}$ The first three meetings focused largely on procedural matters but, with basic processes established, the group still seemed to lack clear direction. A breakthrough occurred at the fourth meeting, in Bali, when, at the direction of ARF ministers, the EEP group began to focus on establishing priorities for preventive diplomacy. A year later, in TimorLeste, a modest set of initiatives for preventive diplomacy was brought forward, including a proposal for what would arguably become the EEP group's most concrete achievement to date: dispatching an election observation team for Timor-Leste's 2012 general elections. ${ }^{53}$ Dibb was the Australian EEP group representative at those elections.

If the EEP group had taken a step forward, from that point onward, it seemed to take two steps back - even as the regional security environment deteriorated in the context of China's newly muscular approach in the East and South China Seas. Ministerial guidance and feedback to the EEP group became more sporadic and less specific. With the exception of Dibb and a few other EEPs, the lack of continuity in terms of EEP group member representatives compounded the problem, depriving the organisation of 'corporate memory'. The attendance of new representatives each year meant spending a substantial amount of time in meetings revisiting old issues rather than progressing on new ones. Geopolitically, divisions began to emerge. Substantively,

52 Australia co-chaired the 2016 meeting in Singapore and will host the event in 2017.

53 Many South-East Asian members did not participate, due to sensitivities about interference in internal affairs. 
the traditional inhibitors of multilateral security cooperation in Asia became more pronounced. In particular, at a time when the need for practical proposals for ameliorating increasing strategic competition among the region's great powers had become more urgent than ever, the norms of non-interference and consensus were asserted to block sensitive discussions and hamper the advancement of key preventive diplomacy initiatives. For Dibb, this was a source of perennial frustration. Created as a Track 1.5 process to develop ideas in the face of these kinds of constraints, the EEP group seemed instead to be headed for the kind of lack of focus that many observers perceived as undermining the ARF.

As for Dibb, his personal contribution to the EEP group process stands in stark contrast to the overall performance of the organisation. Having attended every meeting since its founding and been one of its most active participants, he has served as a crucial source of continuity and corporate memory. From the earliest meetings, and in the face of reluctance, Dibb insisted that institutional relevance, at a minimum, necessitated a focus on 'hard' security issues. Year in and year out, through speeches, working papers (oddly referred to as 'nonpapers'), briefings and negotiations on the margins of meetings, Dibb has helped to lead the EEP group both in critical self-examination and the more substantive work of developing a practical agenda for preventive diplomacy. Displaying immense patience, he has worked assiduously to gain support for a regional 'incidents at sea' accord as a viable component of regional maritime security. He has been a tireless agitator for the need to approach Asia's multilateral security architecture in ways that lead from dialogue to practical cooperation to serve the goals of peace and stability in the region.

\section{Conclusion}

Only a few individuals are able to combine the pragmatism gained from cutting-edge policy experience with the aspirational motivations required to persist in advancing the normative agendas underlying multilateral approaches to regional security politics. Dibb has demonstrated such a dual capacity and, in doing so, has served his nation ably at a transitional time in its history. He was instrumental in advancing Australia's interest in cultivating strategic relations with 
China and Japan at a crucial juncture in the evolution of the AsiaPacific's contemporary security environment. He has been a critical player in developing Australia's role as an effective and active middle power in shaping that region's multilateral security dialogues. He has simultaneously contributed to his country's strategic policy thinking in ways that few of his peers have matched.

The most significant lesson that Dibb's career provides to us is that the very best analysts are those who are willing to apply their intellectual talents to actively shaping those policies that are of vital concern to themselves and to their country. His willingness to contribute to the conceptualisation and development of Australia's approaches to AsiaPacific order-building, especially in the area of regional confidencebuilding, will be remembered as a benchmark for all those who aspire to think about and influence national security policy. 
This text is taken from Geography, Power, Strategy and Defence Policy: Essays in Honour of Paul Dibb, edited by Desmond Ball and Sheryn Lee, published 2016 by ANU Press, The Australian National University,

Canberra, Australia. 